\title{
Cell Block: A Tool to Improve Cytopathologic Diagnostic Value of Fine Needle Aspiration Material
}

\author{
Vaishali Baburao Nagose ${ }^{1 *}$, Shruthi Amit Deshpande ${ }^{2}$, Dinesh Kasturi² and Varsha Ashok Jadhav ${ }^{3}$ \\ ${ }^{1}$ Dept. Of Pathology, Dr Ulhas Patil Medical College \& General Hospital, Jalgaon (Khurd), 425309, Maharashtra, India. \\ ${ }^{2}$ Department of Pathology, Mamata Medical College, Rotary Nagar, Khammam-507002. Telangana. INDIA \\ ${ }^{3}$ Dept. of Pathology, Apollo Institute of Medical Sciences \& Research, Chittoor, Murukambattu, Chittoor, AP, India.
}

\begin{abstract}
Background: The various advantages of Fine-needle aspiration (FNA) biopsy/ cytology can be limited due to inadequacy of the specimen and expertise required for diagnosis. Cell blocks (CBs), though routinely used in cytology of body fluids, can also be used in FNA material with considerable increase in diagnostic accuracy. Aims \& objectives: To compared FNA \& CB as diagnostic tool and to evaluate whether cell block adds to the diagnostic accuracy of FNA.

Methods: This is a two years prospective study carried out in the pathology department of a tertiary heath care hospital and medical college of South India which included the cases undergoing the FNAC, and followed by the biopsy. CB was prepared using Tissue coagulum clot (TCC) method. The smears and tissue sections were assessed for cellularity and adequacy for diagnosis. CBs were grouped into four diagnostic categories. FNA \& CB were compared with histopathology (HPE) diagnosis to calculate Sensitivity, Specificity and Diagnostic Accuracy.

Result: A total of 195 cases were included. Cellularity and adequacy for diagnosis were higher in CB. They were diagnostically better (superior) in $13.84 \%$ (27) cases. The sensitivity (95.77\%) and diagnostic accuracy $(94.87 \%)$ of CB was found to be considerably higher than FNA (78.84\% and $78.46 \%$ respectively).

Conclusion: In cases of suspicious/ intermediate diagnosis or diagnosis discordant with clinical ones, by FNA; should be followed with the CB to improve the diagnostic yield \& to facilitate accurate diagnoses. TCC method is a simple CB method which has higher diagnostic accuracy than FNA.
\end{abstract}

Keywords: FNAC, FNAB, Cell Block, Cytology, Cytopathology, Diagnostic Accuracy.

\section{Introduction}

Fine-needle aspiration (FNA) biopsy/ cytology is an easy, OPD basis, minimally invasive and cost-effective technique with good accuracy and efficiency in routine cytopathology. However, the inadequacy of the specimen can be as high as upto $30 \% .{ }^{[1]}$ Associated is, always a risk of false negative diagnosis or other situations requiring use of experience and expertise for a confidant diagnosis which itself may be limiting the result. ${ }^{[2,3]}$ However, the advantage of histopathology (HPE) over the cytological examination can be obtained by using all the remaining material of the FNA for making cell blocks (CBs) which gives a better morphological and histological detail. Thus, the diagnosis may be refined. Also, the benefit of availability of the multiple sections for special stains and IHC form cell block makes it a desirable practice in the set up with required resources. Both techniques together can improve the diagnostic accuracy, eliminate the need of repeat FNA for non diagnostic cases and avoid the trauma and risks of biopsy. ${ }^{[4]}$
In the present study, we compared these two methods as a diagnostic tool and evaluated whether cell block adds to the diagnostic accuracy of FNA.

\section{Materials and Methods}

The present study was two years prospective study carried out in the pathology department of a tertiary heath care hospital and medical college of South India. The cases undergoing the FNAC, and followed by the biopsy were included.

FNAC was performed under aseptic condition using 21, 22 or 23 gauge needles attached to the $10 \mathrm{ml}$ disposable syringes with or without aspiration as required. Smears were prepared without delay taking care to avoid the coagulation of the sample. All of them were immediately alcohol fixed in 95\% ethyl alcohol for Papanicolaou (Pap) stain \& hematoxylin and eosin (H \& E) stain except a few which were air dried for May Grunwald - Giemsa (MGG) stain and in the suspected cases of Tuberculosis (TB), Zeihl - Neelson stain (ZN stain) for demonstrating Acid Fast Bacilli. 
The method used for preparation of the $\mathrm{CB}$ was Tissue coagulum clot (TCC) method. The material remaining in the needle hub and attached syringe was allowed to clot, later left overnight to fix in the mixture of $10 \%$ formalin and $95 \%$ alcohol (1 part each). The material thus obtained was processed as routine biopsy specimen and the tissue sections were stained with $\mathrm{H} \& \mathrm{E}$ stain.

The smears and tissue sections were assessed for cellularity and adequacy for diagnosis. All the cases were categorized as having abundant, moderate, scant and no cellularity on smears as well as cell block. Again, they were divided into adequate and inadequate. The diagnoses on FNAC were given according to criteria of reporting the various organs smears in the textbook of Orell and textbook of Koss. The cell blocks were also reported separately. They were grouped into 1) Non-Diagnostic/ Diagnosis Discordant with FNA \& HPE 2) Diagnostically equal (same diagnosis as of FNA and HPE), 3) Diagnostically aiding (confirming a suspicious/ possible/ intermediate FNA diagnosis, which was confirmed by same diagnosis on HPE) and 4) Diagnostically Superior (giving a different diagnosis than one of FNA, or giving a specific neoplastic lesion in cases suspicious of malignancy - same diagnosis on HPE). HPE diagnosis was taken as gold standard and the diagnosis of FNA \& CB were compared with it to calculate Sensitivity, Specificity and Diagnostic Accuracy. The statistical analysis was done after recording the complete data on Excel worksheet.

\section{Result}

A total of 195 cases were included in this study with FNA and HPE both samples available. The age of patients ranged from 5 years to 85 years. Thyroid was the most common site for FNA (32.8\%) followed by lymph node, breast, and soft tissue \& bone (Table 1).

Cellularity was better marginally in CB (Table 2). The adequacy for diagnosis was also higher in CB (94.87\%) by a little difference than FNA (92.3\%) (Table 3). Out of the 15 cases found to be inadequate for diagnosis by FNAC, eight cases were adequate by $\mathrm{CB}$. But three of the adequate FNAC cases were inadequate by $\mathrm{CB}$.

On comparison with the HPE diagnosis, CB was found to be diagnostically better (superior) in $13.84 \%$ (27) cases and aiding the final diagnosis in $12.83 \%$ (25) cases than FNA (Table 4). Most of the cases in the former category were from lymph nodes and thyroid. The latter category had maximum cases of suspicious for malignancy diagnosis on FNAC.

The discordant cases on FNA with respect to HPE belonged to lymph nodes (nine cases) and thyroid (seven cases) mainly (Table 1). CB was found to be diagnostically superior in all of these, giving the diagnosis same as HPE. In lymph nodes both neoplastic and non neoplastic lesions were found to have discordant cases, but in all the neoplastic cases of these, the $\mathrm{CB}$ gave correct diagnosis. There were three cases proved to be metastatic deposits of squamous cell carcinoma by $\mathrm{CB}$ and HPE, of which two were diagnosed as suppurative lymph node and another as keratinous cyst on FNA. Similarly, in three breast FNAs, malignancy was correctly diagnosed on $\mathrm{CBs}$, as compared to fibroadenoma with atypia and inconclusive diagnosis given by FNA. Correct typing of the malignancy was evident by $\mathrm{CB}$ in the cases diagnosed as malignancy or suspicious of malignancy from lung masses (five cases) and thyroid (two cases). Also, two cases diagnosed as goiter by FNA were found to be follicular neoplasm on $\mathrm{CB}$, later confirmed to be follicular adenoma. A case of goiter, simple cyst breast and a parasitic cyst each were inconclusive due to lack of cellularity on $\mathrm{CB}$ when FNA was able to give correct diagnosis.

The sensitivity (95.77\%) and diagnostic accuracy (94.87\%) of $\mathrm{CB}$ was found to be considerably higher than FNA (78.84\% and 78.46\% respectively) (Table 4 ).

Table 1: Sources of FNA/ CB with the site-wise discordant cases.

\begin{tabular}{|c|c|c|c|c|c|c|c|c|}
\hline \multirow{2}{*}{$\begin{array}{l}\text { Sr. } \\
\text { no. }\end{array}$} & \multirow[t]{2}{*}{ Site } & \multirow{2}{*}{$\begin{array}{l}\text { No of } \\
\text { cases }\end{array}$} & \multicolumn{2}{|c|}{ FNA diagnosis } & \multirow{2}{*}{$\begin{array}{l}\text { CB diagnosis } \\
\text { in discordant } \\
\text { cases/ ones } \\
\text { with superior } \\
\text { diagnosis }\end{array}$} & \multirow{2}{*}{$\begin{array}{l}\text { HPE Diagnosis } \\
\text { in discordant } \\
\text { cases/ ones } \\
\text { with superior } \\
\text { diagnosis }\end{array}$} & \multirow{2}{*}{$\begin{array}{l}\text { No of } \\
\text { discordant } \\
\text { cases of FNA } \\
\text { vs CB \& HPE }\end{array}$} & \multirow{2}{*}{$\begin{array}{l}\text { No of } \\
\text { discordant } \\
\text { cases of CB } \\
\text { vs FNA \& HPE }\end{array}$} \\
\hline & & & $\mathbf{n}$ & Diagnosis & & & & \\
\hline \multirow[t]{7}{*}{1} & \multirow{7}{*}{$\begin{array}{l}\text { Soft tissue, } \\
\text { bone. }\end{array}$} & \multirow{7}{*}{$\begin{array}{l}30 \\
(15.38 \%)\end{array}$} & 13 & Lipoma & & & & \\
\hline & & & 1 & Reactive I n & Neurofibroma & Neurofibroma & 1 & \\
\hline & & & 6 & Keratinous cyst & & & & \\
\hline & & & 2 & BNST & & & & \\
\hline & & & 6 & Abscess & & & & \\
\hline & & & 1 & Parasitic cyst & Inconclusive & Parasitic cyst & & 1 \\
\hline & & & 1 & Cystic lesion - bone & Giant cell lesion & Giant cell tumour & 1 & \\
\hline
\end{tabular}




\begin{tabular}{|c|c|c|c|c|c|c|c|c|}
\hline \multirow{2}{*}{$\begin{array}{l}\text { Sr. } \\
\text { no. }\end{array}$} & \multirow[t]{2}{*}{ Site } & \multirow{2}{*}{$\begin{array}{l}\text { No of } \\
\text { cases }\end{array}$} & \multicolumn{2}{|c|}{ FNA diagnosis } & \multirow{2}{*}{$\begin{array}{l}\text { CB diagnosis } \\
\text { in discordant } \\
\text { cases/ ones } \\
\text { with superior } \\
\text { diagnosis }\end{array}$} & \multirow{2}{*}{$\begin{array}{l}\text { HPE Diagnosis } \\
\text { in discordant } \\
\text { cases/ ones } \\
\text { with superior } \\
\text { diagnosis }\end{array}$} & \multirow{2}{*}{$\begin{array}{l}\text { No of } \\
\text { discordant } \\
\text { cases of FNA } \\
\text { vs CB \& HPE }\end{array}$} & \multirow{2}{*}{$\begin{array}{l}\text { No of } \\
\text { discordant } \\
\text { cases of CB } \\
\text { vs FNA \& HPE }\end{array}$} \\
\hline & & & $n$ & Diagnosis & & & & \\
\hline \multirow[t]{12}{*}{2} & \multirow[t]{12}{*}{$\begin{array}{l}\text { Lymph } \\
\text { nodes }\end{array}$} & \multirow[t]{12}{*}{$\begin{array}{l}43 \\
(22.05 \%)\end{array}$} & \multirow[t]{2}{*}{13} & \multirow[t]{2}{*}{ Tb In } & $\begin{array}{l}\text { Suppurative In } \\
\text { ( } 2 \text { cases) }\end{array}$ & $\begin{array}{l}\text { Suppurative In } \\
(2 \text { cases })\end{array}$ & 2 & \\
\hline & & & & & $\begin{array}{l}\text { Suppurative In } \\
\text { (1 case) }\end{array}$ & $\mathrm{Tb} \ln (1$ case $)$ & & 1 \\
\hline & & & 9 & Reactive In & $\mathrm{TB} \ln (1)$ & TB $\ln (1)$ & 1 & \\
\hline & & & 4 & Mets - SCC & & & & \\
\hline & & & 1 & ? Keratinous cyst & Mets SCC & Mets SCC & 1 & \\
\hline & & & 1 & Lepromatous In & & & & \\
\hline & & & \multirow[t]{2}{*}{4} & \multirow[t]{2}{*}{ Suppurative In } & $\begin{array}{l}\text { Mets SCC } \\
(2 \text { case }) \\
\text { TB In ( } 2 \text { case }) \\
\end{array}$ & $\begin{array}{l}\text { Mets SCC } \\
(2 \text { case }) \\
\text { TB In ( } 2 \text { case }) \\
\end{array}$ & 4 & \\
\hline & & & & & Abscess (1 case) & $\begin{array}{l}\text { Suppurative In } \\
(1 \text { case })\end{array}$ & & 1 \\
\hline & & & 3 & $\begin{array}{l}\text { Chronic non- } \\
\text { specific In }\end{array}$ & & & & \\
\hline & & & 1 & Hodgkin disease & & & & \\
\hline & & & 2 & NHL & & & & \\
\hline & & & 5 & Inconclusive & $\begin{array}{l}\text { Reactive In } \\
\text { (1 case) } \\
\text { Mets (1 case) } \\
\end{array}$ & $\begin{array}{l}\text { Reactive In } \\
(1 \text { case }) \\
\text { Mets (1 case) } \\
\end{array}$ & 2 & \\
\hline \multirow[t]{6}{*}{3} & \multirow[t]{6}{*}{ Breast } & \multirow[t]{6}{*}{$\begin{array}{l}32 \\
(16.41 \%)\end{array}$} & 13 & Fibroadenoma & $\begin{array}{l}\text { Ca breast } \\
(2 \text { cases })\end{array}$ & $\begin{array}{l}\text { Ca breast } \\
(2 \text { cases })\end{array}$ & 2 & \\
\hline & & & 3 & Breast abscess & & & & \\
\hline & & & 2 & Gynecomastia & & & & \\
\hline & & & 8 & Ca breast & $\begin{array}{l}\text { Atypical } \\
\text { Fibroadenoma } \\
(1 \text { case })\end{array}$ & $\begin{array}{l}\text { Atypical } \\
\text { Fibroadenoma } \\
(1 \text { case })\end{array}$ & 1 & \\
\hline & & & 3 & Simple cyst & $\begin{array}{l}\text { Inconclusive } \\
(1 \text { case })\end{array}$ & $\begin{array}{l}\text { Simple cyst } \\
(1 \text { case })\end{array}$ & & 1 \\
\hline & & & 3 & Inconclusive & $\begin{array}{l}\text { Ca breast } \\
(1 \text { case })\end{array}$ & $\begin{array}{l}\text { Ca breast } \\
\text { (1 case) }\end{array}$ & 1 & \\
\hline \multirow[t]{8}{*}{4} & \multirow[t]{8}{*}{ Thyroid } & \multirow{8}{*}{$\begin{array}{l}61 \\
(31.28 \%)\end{array}$} & 3 & Neoplastic & PCT ( 2 cases) & PCT ( 2 cases) & 2 & \\
\hline & & & 3 & PCT & & & & \\
\hline & & & 3 & Follicular neoplasm & & $\begin{array}{l}\text { Follicular } \\
\text { adenoma }\end{array}$ & & \\
\hline & & & \multirow[t]{2}{*}{32} & \multirow[t]{2}{*}{ Goiter } & $\begin{array}{l}\text { Follicular } \\
\text { neoplasm } \\
\text { (2 cases) } \\
\end{array}$ & $\begin{array}{l}\text { Follicular } \\
\text { adenoma } \\
(2 \text { cases })\end{array}$ & 2 & \\
\hline & & & & & $\begin{array}{l}\text { Inconclusive } \\
(1 \text { case })\end{array}$ & Goiter (1 case) & & 1 \\
\hline & & & 7 & Thyroiditis & $\begin{array}{l}\text { Inconclusive } \\
(1 \text { case })\end{array}$ & $\begin{array}{l}\text { Thyroiditis } \\
(1 \text { case }) \\
\end{array}$ & & 1 \\
\hline & & & 9 & Benign cystic lesion & $\begin{array}{l}\text { Thyroiditis } \\
(1 \text { case })\end{array}$ & $\begin{array}{l}\text { Thyroiditis } \\
\text { ( } 1 \text { case })\end{array}$ & 1 & \\
\hline & & & 4 & Inconclusive & $\begin{array}{l}\text { Goiter (1 case) } \\
\text { Thyroiditis } \\
(1 \text { case })\end{array}$ & $\begin{array}{l}\text { Goiter (1 case) } \\
\text { Thyroiditis } \\
(1 \text { case })\end{array}$ & 2 & \\
\hline
\end{tabular}




\begin{tabular}{|c|c|c|c|c|c|c|c|c|}
\hline \multirow{2}{*}{$\begin{array}{l}\text { Sr. } \\
\text { no. }\end{array}$} & \multirow[t]{2}{*}{ Site } & \multirow{2}{*}{$\begin{array}{l}\text { No of } \\
\text { cases }\end{array}$} & \multicolumn{2}{|c|}{ FNA diagnosis } & \multirow{2}{*}{$\begin{array}{l}\text { CB diagnosis } \\
\text { in discordant } \\
\text { cases/ ones } \\
\text { with superior } \\
\text { diagnosis } \\
\end{array}$} & \multirow{2}{*}{$\begin{array}{l}\text { HPE Diagnosis } \\
\text { in discordant } \\
\text { cases/ ones } \\
\text { with superior } \\
\text { diagnosis } \\
\end{array}$} & \multirow{2}{*}{$\begin{array}{l}\text { No of } \\
\text { discordant } \\
\text { cases of FNA } \\
\text { vs CB \& HPE }\end{array}$} & \multirow{2}{*}{$\begin{array}{l}\text { No of } \\
\text { discordant } \\
\text { cases of CB } \\
\text { vs FNA \& HPE }\end{array}$} \\
\hline & & & $\mathbf{n}$ & Diagnosis & & & & \\
\hline \multirow[t]{4}{*}{5} & \multirow[t]{4}{*}{$\begin{array}{l}\text { Salivary } \\
\text { gland }\end{array}$} & \multirow[t]{4}{*}{$\begin{array}{l}10 \\
(5.13 \%)\end{array}$} & 1 & Myoepithelioma & $\begin{array}{l}\text { Pleomorphic } \\
\text { adenoma }\end{array}$ & $\begin{array}{l}\text { Pleomorphic } \\
\text { adenoma }\end{array}$ & 1 & \\
\hline & & & 5 & $\begin{array}{l}\text { Pleomorphic } \\
\text { adenoma }\end{array}$ & & & & \\
\hline & & & 3 & Sialadinitis & Abscess (1 case) & $\begin{array}{l}\text { Sialadinitis } \\
\text { (1 case) }\end{array}$ & & 1 \\
\hline & & & 1 & Inconclusive & $\begin{array}{l}\text { Pleomorphic } \\
\text { adenoma }\end{array}$ & $\begin{array}{l}\text { Pleomorphic } \\
\text { adenoma }\end{array}$ & 1 & \\
\hline \multirow[t]{4}{*}{6} & \multirow[t]{4}{*}{ Skin subcut } & \multirow[t]{4}{*}{$\begin{array}{l}6 \\
(3.08 \%)\end{array}$} & 1 & Keratinous cyst & & & & \\
\hline & & & 1 & Keloid & & & & \\
\hline & & & 2 & SCC & & & & \\
\hline & & & 1 & Inconclusive & $\begin{array}{l}\text { ? Spindle cell } \\
\text { lesion }\end{array}$ & Fibrotic lesion & 1 & \\
\hline \multirow[t]{3}{*}{7} & \multirow[t]{3}{*}{ Lung, pleura } & \multirow[t]{3}{*}{$\begin{array}{l}10 \\
(5.13 \%)\end{array}$} & 4 & Koch's & & & & \\
\hline & & & 5 & Malignant & $\begin{array}{l}\text { SCC ( } 3 \text { cases), } \\
\text { Adenocarcinoma } \\
\text { ( } 2 \text { cases })\end{array}$ & $\begin{array}{l}\text { SCC ( } 3 \text { cases), } \\
\text { Adenocarcinoma } \\
\text { ( } 2 \text { cases })\end{array}$ & & \\
\hline & & & 1 & Inconclusive & s/o Malignancy & SCC & 1 & \\
\hline 8 & Oral cavity & $\begin{array}{l}3 \\
(1.54 \%)\end{array}$ & 3 & SCC & & & & \\
\hline \multicolumn{2}{|c|}{ Total } & \multicolumn{5}{|l|}{195} & 27 & 7 \\
\hline
\end{tabular}

Table 2: Cellularity in FNA vs CB.

\begin{tabular}{|c|c|c|}
\hline Cellularity & FNA & CB \\
\hline Abundant & $41(21.10 \%)$ & $104(53.34 \%)$ \\
\hline Moderate & $104(53.34 \%)$ & $41(21.10 \%)$ \\
\hline Scant & $42(22.16 \%)$ & $4(2.04 \%)$ \\
\hline No cellularity & $7(3.4 \%)$ & $195(100 \%)$ \\
\hline Total cases & $195(100 \%)$ & \\
\hline
\end{tabular}

Table 3: Distribution of adequacy between FNAC \& CB.

\begin{tabular}{|l|l|l|l|l|}
\hline \multicolumn{2}{|c|}{} & \multicolumn{2}{l|}{ FNAC } & Total \\
\cline { 3 - 6 } \multicolumn{2}{|c|}{} & Adequate & Inadequate & \\
\hline \multirow{2}{*}{ Cell Block } & Adequate & $177(90.77 \%)$ & $8(4.1 \%)$ & $185(94.87 \%)$ \\
\cline { 2 - 5 } & Inadequate & $3(1.53 \%)$ & $7(3.6 \%)$ & $10(5.13 \%)$ \\
\hline \multicolumn{2}{|l|}{ Total } & $\mathbf{1 8 0}(\mathbf{9 2 . 3} \%)$ & $\mathbf{1 5 ( 7 . 7 0 \% )}$ & $\mathbf{1 9 5}(\mathbf{1 0 0 \% )}$ \\
\hline
\end{tabular}

Table 4: Diagnostic categories of CB and Statistics.

\begin{tabular}{|l|l|l|}
\hline \multicolumn{2}{|l|}{ Diagnostic categories of CB } & $\mathbf{n}(\%)$ \\
\hline & Diagnostically Superior & $27(13.84 \%)$ \\
\hline & Diagnostically aiding & $25(12.83 \%)$ \\
\hline & Diagnostically equal & $129(66.15 \%)$ \\
\hline
\end{tabular}




\begin{tabular}{|c|c|c|c|}
\hline \multicolumn{2}{|c|}{ Diagnostic categories of CB } & \multicolumn{2}{|c|}{$\mathrm{n}(\%)$} \\
\hline & $\begin{array}{l}\text { Non-Diagnostic (HPE } \\
\text { diagnostic)/ CB Diagnosis } \\
\text { Discordant with FNA \& HPE }\end{array}$ & \multicolumn{2}{|c|}{$14(7+7),(7.18 \%)$} \\
\hline \multicolumn{2}{|l|}{ Diagnosis } & FNA [n (\%)] & CB [n (\%)] \\
\hline True Positive & $\begin{array}{l}\text { Offered Diagnosis same as } \\
\text { HPE }\end{array}$ & $149(76.41 \%)$ & $181(92.82 \%)$ \\
\hline True Negative & $\begin{array}{l}\text { Inconclusive, HPE as well } \\
\text { Inconclusive }\end{array}$ & $4(2.05 \%)$ & $4(2.05 \%)$ \\
\hline \multirow[t]{2}{*}{ False Negative } & $\begin{array}{l}\text { Offered Diagnosis different } \\
\text { from HPE }\end{array}$ & $29(14.87 \%)$ & $2(1.03 \%)$ \\
\hline & Inconclusive, HPE Diagnostic & $11(5.64 \%)$ & $6(3.08 \%)$ \\
\hline False Positive & $\begin{array}{l}\text { Diagnosis offered, HPE } \\
\text { inconclusive }\end{array}$ & $2(1.03 \%)$ & $2(1.03 \%)$ \\
\hline \multicolumn{2}{|l|}{ Sensitivity } & $78.84 \%$ & $95.77 \%$ \\
\hline \multicolumn{2}{|l|}{ Specificity } & $66.67 \%$ & $66.67 \%$ \\
\hline \multicolumn{2}{|l|}{ Diagnostic Accuracy } & $78.46 \%$ & $94.87 \%$ \\
\hline
\end{tabular}

Table 5: Comparison of adequacy, sensitivity, specificity and diagnostic accuracy of FNA \& CB in recent Indian works.

\begin{tabular}{|c|c|c|c|c|c|c|c|c|c|}
\hline \multirow[t]{2}{*}{ Author } & \multirow{2}{*}{$\begin{array}{l}\text { Site - if } \\
\text { specific }\end{array}$} & \multicolumn{2}{|c|}{ Adequacy } & \multicolumn{2}{|c|}{ Sensitivity } & \multicolumn{2}{|c|}{ Specificity } & \multicolumn{2}{|c|}{ Diagnostic Accuracy } \\
\hline & & FNA & CB & FNA & CB & FNA & CB & FNA & CB \\
\hline Wadhwa et al. ${ }^{[18]}$ & HNF & & & $88.8 \%$ & $96 \%$ & -- & $100 \%$ & $92 \%$ & $97.67 \%$ \\
\hline Parate et al. ${ }^{[19]}$ & & $90 \%$ & $86.94 \%$ & $88.06 \%$ & $90.91 \%$ & $92.86 \%$ & $92.86 \%$ & $89.47 \%$ & $91.47 \%$ \\
\hline Mathew et al. ${ }^{[20]}$ & GFNA & $100 \%$ & $100 \%$ & $62.22 \%$ & $71.11 \%$ & $100 \%$ & $100 \%$ & $63.04 \%$ & $71.73 \%$ \\
\hline Barsagade et al. ${ }^{[21]}$ & & $81.85 \%$ & $79.25 \%$ & & & & & & \\
\hline Patil et al..$^{[22]}$ & & $87.83 \%$ & $81.08 \%$ & $94.90 \%$ & $98.92 \%$ & $93.75 \%$ & $96.30 \%$ & $94.61 \%$ & $98.33 \%$ \\
\hline Present study & & $92.3 \%$ & $94.87 \%$ & $78.84 \%$ & $95.77 \%$ & $66.67 \%$ & $66.67 \%$ & $78.46 \%$ & $94.87 \%$ \\
\hline
\end{tabular}

HNF - Head Neck Face, GFNA - Guided FNAs.

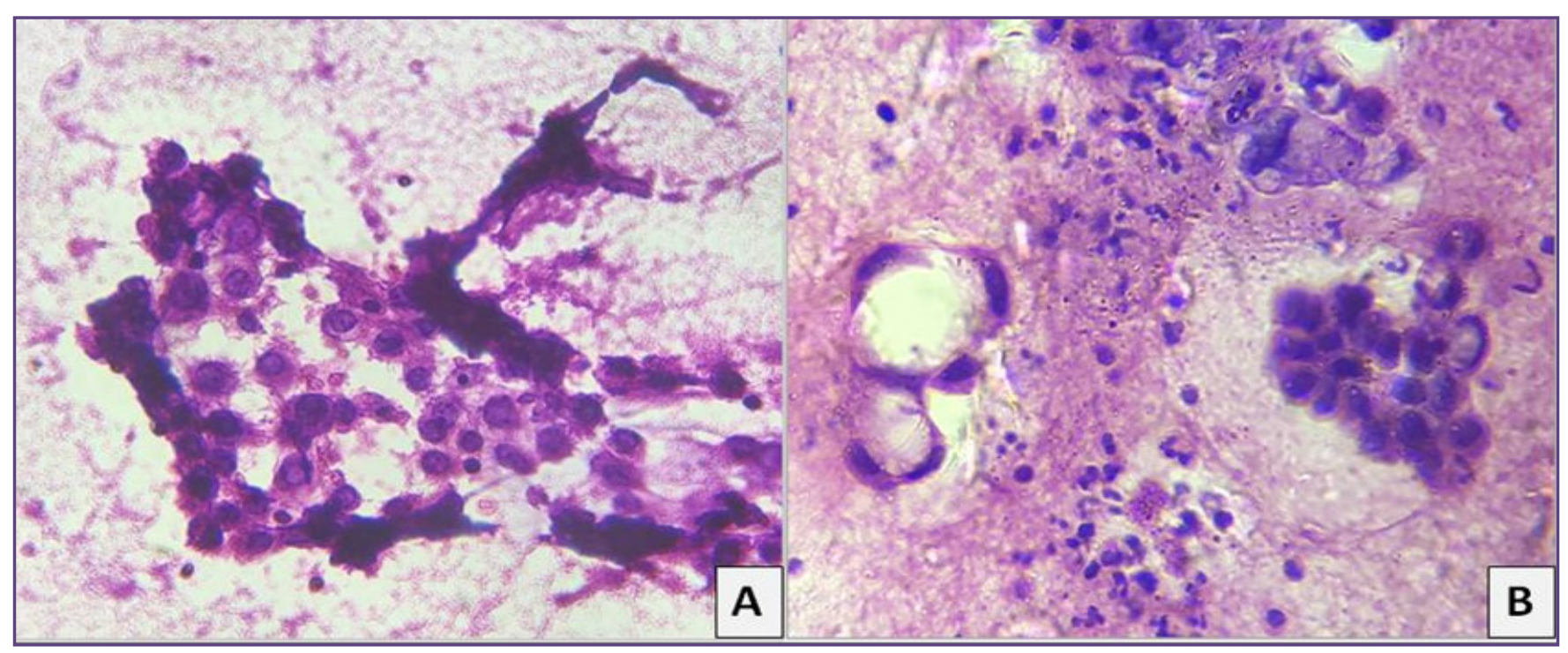

Fig. 1 a - Smear prepared from FNAC lung mass showing loosely cohesive malignant epithelial cells. (400x MGG). Other fields showed doubtful signet ring cells as well. Figure 1 b - corresponding cell block showing acini and signet ring cells. (400x $\mathrm{H} \& \mathrm{E}$ ). 


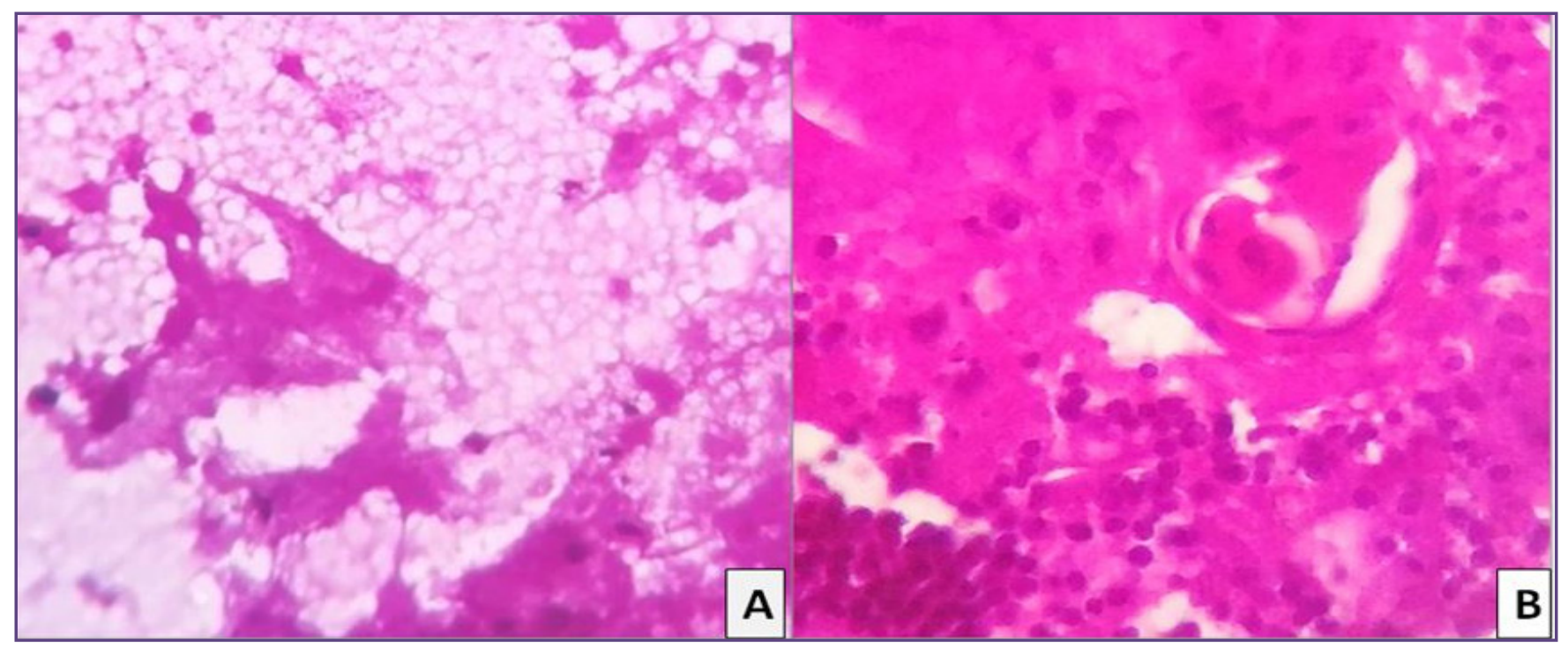

Fig. 2 a - Smear prepared from FNAC right submandibular lymph node. Shows few anucleate and nucleated squamous cells only, with occasional dysplastic squamous cells and mononuclear inflammatory infiltrate. (400x H \& E). Figure 2 b - corresponding cell block showing keratin pearl with surrounding lymphocytes. (400x H \& E).

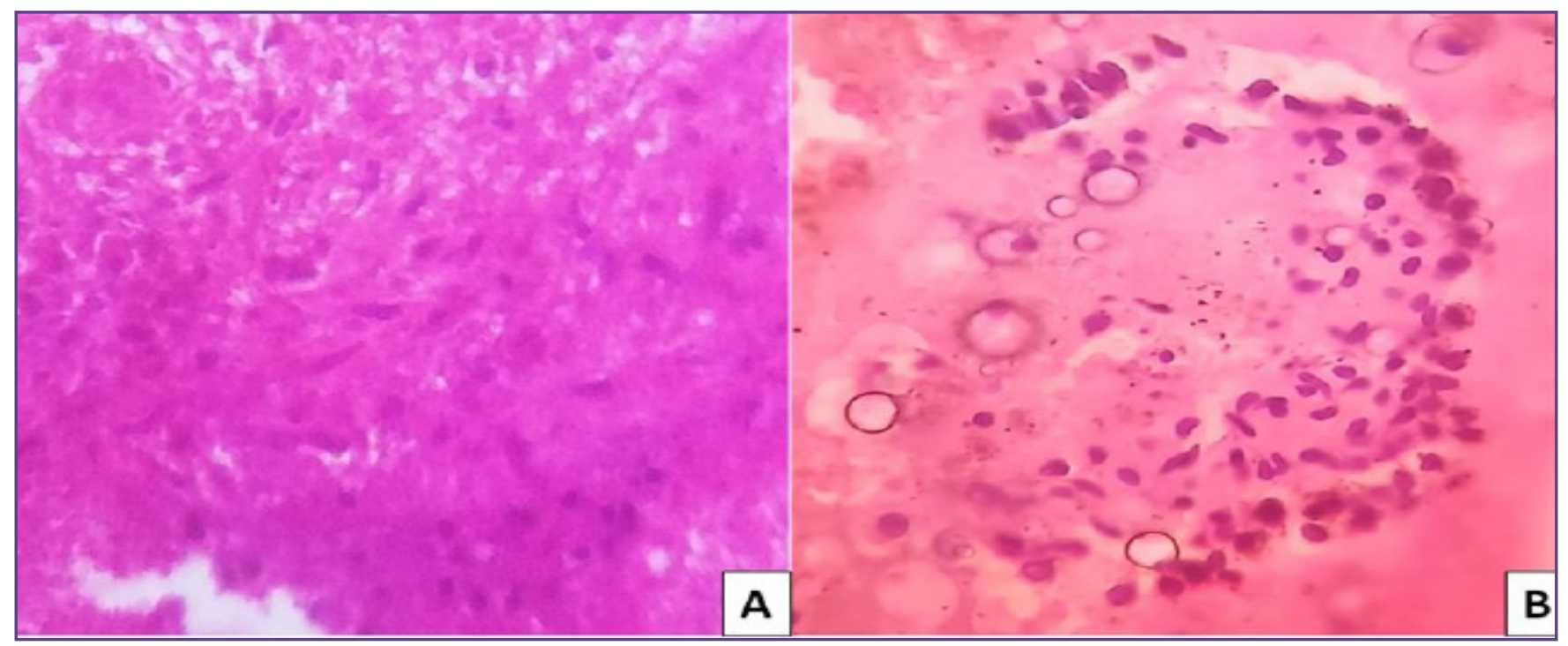

Figure 3 a \& b - Cell block showing ill formed epitheloid cell granuloma formation. (400x H \& E). The corresponding FNAC smears showed only scant cellularity comprising of few lymphocytes with occasional epitheloid cell.

\section{Discussion}

The history of FNA for the diagnosis of the neoplastic lesion goes back to 1847 , then described as a "new instrument for the diagnosis of tumors" by Kun. Afterwards it was applied by various practitioners to different sites.

Cell block technique was first used almost a century ago by Bahrenburg (in1896), approximately five decades later to FNA initial use, as an alternative to the preparation of conventional smear from ascitic fluid. ${ }^{[5]}$ Since then, other than various fluids, it has also been prepared from hemorrhagic aspirates. ${ }^{[6,7]}$ To the various advantages of FNA, it adds diagnostic architecture just as a histological diagnosis. ${ }^{[8]}$ Another very important virtue is that multiple sections can be taken from the cell block to be used for special staining and IHC other than routine staining. $[9,10]$

CBs have been popularly prepared from the material of FNA by paraffin- embedding the direct transfer of all centrifuged cellular material wrapped in lens paper, ${ }^{[11,12]}$ or embedding in plasma, ${ }^{[13,14]}$ or agar. ${ }^{[15,16]}$ Afterwards it is processed as a routine histological specimen. The Tissue 
coagulum clot (TCC) method has an advantage over the conventional aspiration needle rinse in the recovery of cellular material and prevention of the loss of diagnostic material. Also, there is no requirement of any special equipment or reagents in TCC method. ${ }^{[17]}$ This makes it feasible method in any modest laboratory.

Less dispersal of the cells in the $\mathrm{CBs}$, may result in improved adequacy and ease at microscopic examination. The adequacy of the CBs has been found to be $79.25 \%$ to $100 \%$ by the recent works, with concordant finding in the present one (94.87\%) as well (Table 5). ${ }^{[18-22]}$ It is little less than or equal to that of FNA in all, but we found the adequacy to be a bit higher than that of FNA. The possible reason may be the high dependence of FNA on the expertise of the person performing the aspiration. Also, if the blood appears in the needle hub, the diagnostic material may be sucked in syringe; as a result it will be processed in CBs, against hemorrhagic FNA smears. ${ }^{[23]} \mathrm{A}$ common finding is increase in adequacy when the two methods are combined. $[21,22]$

The $\mathrm{CBs}$ are known to show additional diagnostic information along with architectural patterns, than FNAC smears aiding in increased diagnostic accuracy with them and confirmation of many suggestive/ suspicious/ intermediate diagnosis by FNA. ${ }^{[21,22]}$ The present work has same finding. The architectural features better appreciated in $\mathrm{CB}$ included gland formation of malignant cells in adenocarcinomas in lung aspirate (Figure 1), keratin pearl formation in lymph node (Figure 2) and lung lesion aspirates in SCC. The epitheloid granulomas were seen in a lymph node aspirate $\mathrm{CB}$ when only necrotic material and scant chronic inflammatory infiltrate seen in smears (Figure 3).

As widely known, the $\mathrm{CB}$ is contributory in only upto one third of cases in the diagnosis of thyroid lesions. One of the main causes is the low cellularity, and yet another cause may be hemorrhagic nature of the thyroid aspirates. ${ }^{[24,25]}$ The case inconclusive by CB in our work was due to very low cellularity and colloid being better appreciated in the smears. The neoplastic lesions could be confirmed and subtyped due the architectural details available from $\mathrm{CB}$ including papillary arrangement in PCT. The findings are similar to some recent works showing better $\mathrm{CB}$ diagnosis than FNA from thyroid. ${ }^{[18,22]}$

In lung carcinoma $\mathrm{CB}$ is important in the subtyping of by morphology, ${ }^{[26]}$ and also in IHC for squamous and adenocarcinoma markers. ${ }^{[27]}$ Endobronchial ultrasoundguided transbronchial needle aspirates (EBUSTBNAs) samples' CBs have been found to yield adequate tissue for cytological analysis in over $97 \%$ of cases. ${ }^{[28,29]}$ Similarly, in the present study and yet another recent one, ${ }^{[22]}$ correct typing of the malignancy was done in the lung masses by $\mathrm{CB}$, where FNA gave diagnosis of malignancy.

Another site with noticeable role of $\mathrm{CB}$ in this research was breast lesions where they confirmed, ruled out or diagnosed malignancy against suspicious malignancy cases, negative ones in FNA or inadequate ones respectively. This is concordant with other Indian works. [21, 22] The possible cause may be better appreciation of cellular and architectural details of the cellular material entangled in the hemorrhagic aspirate. Also, in lymph nodes the cases of malignant deposits either missed or misdiagnosed on the FNA were correctly diagnosed in $\mathrm{CB}$, as in other studies. ${ }^{[21,22]}$

The sensitivity, specificity and diagnostic accuracy of $\mathrm{CB}$ has been found to be higher than FNA in the recent works (Table 6). ${ }^{[18-22]}$ The present study found the sensitivity and diagnostic accuracy of $\mathrm{CB}$ more than FNA; and same specificity of $\mathrm{CB}$ and FNA. Concordant finding is present in another work. ${ }^{[19]}$ If only neoplastic diagnoses are considered, then the specificity is found to be very high.

Despite all the above positive findings, CBs were found have longer processing time, due to histopathology processing to be used in them and the cost would increase due to additional method. However, in cases where the FNA has not been diagnostic should be followed with the $\mathrm{CB}$ to increase the diagnostic rate and accuracy.

\section{Conclusion}

The less frequently used technique of Cell block actually allows the recovery and use of even minimum amounts of diagnostic cellular material, thus facilitating the correct diagnosis when FNA is not conclusive or does not give correct diagnosis. TCC method being a simple method, not requiring special reagents or expertise to handle the specimen; is feasible in any resource limited laboratory. CBs give advantage of HPE from the cytology sample. Thus, cases where the FNA has given inaccurate/ suspicious/ intermediate diagnosis should be followed with the $\mathrm{CB}$ to improve the diagnostic yield \& to facilitate accurate diagnosis.

\section{Acknowledgements}

We would like to extend our sincere thanks to all the staff of the department of Pathology, Mamata Medical College and Hospital, Khammam for their support for this work. 


\section{Funding}

None

\section{Competing Interests}

None

\section{Reference}

1. Singh N, Ryan D, Berney D, Calaminici M, Sheaff MT, Wells CA. Inadequate rates are lower when FNAC samples are taken by cytopathologists. Cytopathology. 2003 Dec 1;14(6):327-31.

2. Basnet S, Talwar OP. Role of cell block preparation in neoplastic lesions. Journal of Pathology of Nepal. 2012;2:272-276.

3. Kulkarni MB, Prabhudesai NM, Desai SB, Borges AM. Scrape cell block technique for fine needle aspiration cytology smears. Cytopathology. 2000;11:179-84.

4. Buscarini L, Fornari F, Bolondi L, Colombo P, Livraghi T, Magnolfi F, Rapaccini GL, Salmi A. Ultrasound-guided fineneedle biopsy of focal liver lesions: techniques, diagnostic accuracy and complications: a retrospective study on 2091 biopsies. Journal of hepatology. 1990 Nov 1;11(3):344-8.

5. Bhatia P, Dey P, Uppal R, Shifa R, Srinivasan R, et al. Cell blocks from scraping of cytology smear: Comparison with conventional cell block. ActaCytol. 2008;52:329-333.

6. Bodele AK, Parate SN, Wadadekar AA, Bobhate SK, Munshi MM. Diagnostic utility of cell block preparation in reporting fluid cytology. J Cytol. 2003;20:133-135.

7. Qui L, Crapanzano JP, Saqi A, Vidhun R, Vazquez MF. Cell block alone as an ideal preparatory method for hemorrhagic thyroid nodule aspirates procured without onsite cytologists. Acta Cytol. 2008;52:139-144.

8. Khan AJ, Hingway SR, Raut WK. A new cost- effective cell block technique for optimisation of fine needle aspirates in bone Lesions. International journal of medical and applied sciences. 2013;2:324-333.

9. Zito FA, Gadaleta CD, Salvatore C, Filático R, Labriola A, et al. A modified cell block technique for fine needle aspiration cytology. Acta Cytol. 1995;39:93-99.

10. Krogerus LA, Anderson LC. A simple method for the preparation of paraffin-embedded cell blocks from fine needle aspirates, effusions and brushings. Acta Cytol. 1998;32:585-587.

11. Brown KT, Fulbright RK, Avitabile AM, Bashist B. Cytologic analysis in FNA biopsy: Smears versus cell blocks. AJR Am J Roentgenol 1993;161:629-31.

12. Wojcik EM, Selvaggi SM. Comparison of smears and cell blocks in the fine needle aspiration diagnosis. Acta Cytol 1991;35:773-6.

13. Karnanuchow PN, Bouin RE. Cell block technique for fine needle aspiration biopsy. J Clin Pathol. 1992;35:688.
14. Burt AD, Smillie D, Cowan MD, Adams FG. Fine needle aspiration cytology: Experience with a cell block technique. J Clin Pathol. 1986;39:114-5.

15. Kung IT, Yuen RW. Fine needle aspiration of the thyroid. Distinction between colloid nodule and follicular neoplasm using cell blocks \& 21 gauze needles. Acta Cytol. 1989;33:53-60.

16. Kung IT, Chan SK, Lo ES. Application of the immunoperoxidase technique to cell blocks preparations from the fine needle aspirates. Acta Cytol. 1990;34:297-303.

17. Jain D, Mathur SR, Iyer VK. Cell blocks in cytopathology: a review of preparative methods, utility in diagnosis and role in ancillary studies. Cytopathology. 2014;25(6):356-71. doi: 10.1111/cyt.12174. Epub 2014 Aug 11.

18. Wadhwa K, Bagga PK, Singh B, Paul S. Comparative Analysis of Cell Block Preparation Versus Smear Examination in the Fine Needle Aspirates of Head \& Neck Lesions with Application of IHC Markers on Cell Block Preparation. International Journal of Contemporary Medical Research. 2019 June;6(6): F45-F49. DOI: http://dx.doi. org/10.21276/ijcmr.2019.6.6.42

19. Parate SN, Pawar PS, Kakade A. Role of Cell Block Preparation in Cytopathological Diagnosis. International Journal of Contemporary Medical Research 2019 July;6(7):G26- G31. DOI: http://dx.doi.org/10.21276/ ijcmr.2019.6.7.47

20. Mathew EP, Nair V. Role of cell block in cytopathologic evaluation of image-guided fine needle aspiration cytology. J Cytol. 2017;34:133-8. Available from: http://www.jcytol. org/text.asp?2017/34/3/133/208112

21. Barsagade AK, Umap P, Deshpande A, Male P, Dhadas A, Jungare A et al. Diagnostic Utility of Cell Block Preparation of Fine Needle Aspiration Material. Sch. J. App. Med. Sci., Dec 2017; 5(12D): 5031-5037.

22. Patil RN, Mahore SD, Kolhe HS, Bothale KA, Gowardhan VP, Taori HS, et al. Cell Block Technique: An Effective Tool in Diagnostic Cytopathology. IOSR-JDMS. 2016 Dec;15(12):99-106.

23. Dahnert WF, Hoagland MH, Hamper UM, Erozan YS, Peirce JC. Fine needle aspiration biopsy of abdominal lesions: Diagnostic yield of different needle tip configurations. Radiology. 1992;185:263-8.

24. Sanchez N, Selvaggi SM. Utility of cell blocks in the diagnosis of thyroid aspirates. Diagn Cytopathol 2006;34:89-92.

25. Saleh HA, Hammoud J, Zakaria R, Khan AZ. Comparison of Thin-Prep and cell block preparation for the evaluation of thyroid epithelial lesions on fine needle aspiration biopsy. CytoJournal 2008;5:3.

26. Loukeris K, Vazquez MF, Sica G et al. Cytological cell blocks: predictors of squamous cell carcinoma and adenocarcinoma subtypes. Diagn Cytopathol 2012; 40:380-7. 
27. Righi L, Graziano P, Fornari A et al. Immunohistochemical subtyping of nonsmall cell lung cancer not otherwise specified in fine-needle aspiration cytology: a retrospective study of 103 cases with surgical correlation. Cancer 2011;117:3416-23.

28. Esterbrook G, Anathhanam S, Plant PK. Adequacy of endobronchial ultrasound transbronchial needle aspiration samples in the subtyping of non-small cell lung cancer. Lung Cancer 2013;80:30-4.

29. Collins BT. Endobronchial ultrasound fine-needle aspiration biopsy of pulmonary non-small cell carcinoma with subclassification by immunohistochemistry panel. Cancer Cytopathol 2013;121:146-54.

*Corresponding author:

Dr. Vaishali Baburao Nagose, C/o Dr Shivanand Rathod, Flat no 306, B wing, Gyan Chetna Residency, Opposite Godavari College of Engineering,

Bhusawal Road, Jalgaon, 425001, Maharashtra. INDIA

Phone: +91 8500571871, 7025740648

Email: vaishali.nagose@gmail.com

Date of Submission : 19/05/2020

Financial or other Competing Interests: None. 